\title{
Article
}

\section{Transnational mobility, strong states, and contested sovereignty: Learning from the ChinaTaiwan context}

\author{
Momesso, Lara and Lee, Chun-yi \\ Available at http://clok.uclan.ac.uk/21073/ \\ Momesso, Lara ORCID: 0000-0002-4042-9384 and Lee, Chun-yi (2017) \\ Transnational mobility, strong states, and contested sovereignty: Learning \\ from the ChinaTaiwan context. Asian and Pacific Migration Journal, 26 (4). pp. \\ 459-479. ISSN 0117-1968
}

It is advisable to refer to the publisher's version if you intend to cite from the work. http://dx.doi.org/10.1177/0117196817747102

For more information about UCLan's research in this area go to http://www.uclan.ac.uk/researchgroups/ and search for <name of research Group>.

For information about Research generally at UCLan please go to http://www.uclan.ac.uk/research/

All outputs in CLoK are protected by Intellectual Property Rights law, including Copyright law. Copyright, IPR and Moral Rights for the works on this site are retained by the individual authors and/or other copyright owners. Terms and conditions for use of this material are defined in the policies page.

\section{CLoK}

Central Lancashire online Knowledge www.clok.uclan.ac.uk

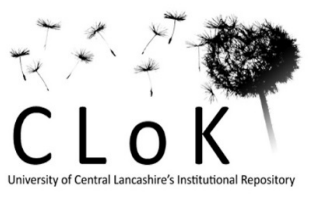


Transnational mobility, strong states, and contested sovereignty: Learning from the ChinaTaiwan context

\begin{abstract}
Mobility across the Taiwan Strait has intensified since the border was opened in 1987 . The crossborder social, cultural and economic exchanges, however, have remained closely embedded in the nationalistic logic specific to cross-Strait relations. Employing a state-centered approach and building on a comparative analysis of the interaction between Beijing and two groups of crossStrait migrants (mainland spouses in Taiwan, and Taiwanese investors in China), this paper examines the various ways in which a state may still exert influence over migrant communities in a context of increased mobility and exchanges. This paper argues that the nation-state may still shape migrants' experiences, particularly when sending and receiving governments have unresolved disputes. Under these conditions, state actors may use migrant communities to achieve their nationalistic goals.
\end{abstract}


Keywords: cross-Strait migrations, cross-Strait relations, state interests, nationalism, Lupeis, Taishangs

\section{Introduction}

In 1987, the ban on social and economic exchanges across the Taiwan Strait was lifted, marking the beginning of a new era for renewed interactions between Taiwan and China after almost four decades. The exchanges across the Strait blossomed and intensified in the following years, fostered by shared culture, ancestral roots and language. These interactions did not only reflect cross-Strait relations but also broader trends brought about by the opening up of China to the world. Harding (1993: 673) described these changes as follows:

Families divided since 1949 longed for reunion. Overseas Chinese wanted the opportunity to visit their native places, historical sites or scenic spots on the mainland. Artists and performers wished to exchange their work; intellectuals and scientists were eager to share their views on topics of common concern. Ordinary Chinese wanted to enjoy the stimulation of films, songs and literature produced in their own language but in a different social setting.

Cross-Strait movements, though, developed in an uneven fashion. As a matter of fact, they involved mainly Taiwanese citizens, first veterans of the Nationalist Army and later all other Taiwanese citizens, except individuals active in the military police or civil service. According to a report by the Mainland Affairs Council (2016), 87,680,700 Taiwanese tourists crossed the border to China from 1987 up until December 2015, whereas only 20,001,200 Chinese people visited Taiwan from 1987 up until December 2015 (the great majority of these people crossed the border after 2010). The direction of investments was also mostly from Taiwan to China. Taiwanese investments in China continued to grow such that by 2015 , direct investments in the mainland surpassed USD 150 billion, which corresponded to 60 percent of all Taiwanese outward direct investment (Mainland Affairs Council, 2015). Thus, this in-flow of people, culture, ideas and commodities to China was not matched by an equivalent out-flow from China. It remained difficult, if not impossible, for Chinese citizens to independently cross the Strait, as 
restrictions by both governments limited extensively the opportunities of movements for mainland Chinese citizens who wanted to go to Taiwan. Migration for marriage could have been an alternative solution, the only available, to the restrictions imposed on the movements across the Strait for those who lived in the PRC. Consequently, different patterns of migration emerged across the Strait: if movements from Taiwan to China were often motivated by investing aims, movements from China to Taiwan were motivated by marriage and family formation.

However, in view of the unsolved conflict between Beijing and Taipei over the legitimacy of the territories of Taiwan, these exchanges could have different implications beyond the economic and family spheres. Hence, in a contest of contested sovereignty over the territory of Taiwan, the two governments turned these migration phenomena into means to promote and eventually achieve their nationalistic goals.

This paper argues that despite the liberalization of cross-border movements and the apparent weakening of state's authority over territory, goods and people, certain states may find an opportunity to strengthen their nationalistic aims in cross-border exchanges and movements. In these contexts, the state's influence over migrants may not only take the form of restrictive and controlling actions over their movement and access to citizenship rights, but also in the concessions and privileges offered to certain migrant communities for the purpose of achieving the state's nationalistic goals.

Similarly, in the cross-Strait case, increased movements across the border may paradoxically strengthen the objectives of Beijing, the actor pushing for reunification across the Strait. In a context of increased cross-Strait mobility, Beijing's ideal of unity and continuity across the Strait may be reinforced at the expenses of Taipei's claims of division and autonomy. It is clear that in this context, state actors preserve, if not increase, their power and authority in spite of, if not as a consequence of, increased mobility across the border.

This paradox can be appreciated through an analysis centered on state actions in response to cross-Strait migrations. If both Taipei and Beijing used cross-Strait migrants as a means to strengthen their nationalistic aims, in this paper we will focus on the actions initiated by the latter as an opening up of the border constituted an opportunity, rather than a loss, for Beijing. Indeed, 
it meant the opportunity to waver its main goal of achieving national unity across the Strait, and, in this way, extending its authority over an area that, although ideally part of China, is not directly under its control. Furthermore, while much scholarship focused on Taiwan has explored the Taiwanese state's actions toward cross-Strait migrant communities (Friedman, 2010; Keng and Schubert, 2010; King, 2010; Liao, 2008), little is known about the Chinese state' s actions. Thus, this paper aims to fill this gap and to bring cross-Strait migrations beyond the scholarship on Taiwan Studies, as a useful case study to explore states' responses to contemporary flows of crossborder movements. Although the focus of this paper is on Beijing, we still maintain that Taipei holds a crucial role in shaping the behavior of the Chinese state and in framing part of the opportunities and constraints of migrant communities. In light of these reflections and focusing on Beijing's actions toward mainland spouses married to Taiwanese men and residing in Taiwan (Lupeis) and Taiwanese businessmen residing in China (Taishangs), this paper aims to explore how and to what extent state actors they take advantage of transnational mobilities to strengthen their nationalistic goals.

Data for this paper were drawn from our extensive research on Taishangs in China and mainland spouses in Taiwan. The data on Taiwanese businessmen were based on interviews with Taishangs from 2004 to 2009 in three cities in China: Tianjin, Kunshan and Dongguan. This time period corresponded to the first eight years in which the Democratic Progressive Party (DPP) was in power (2000-2008) in Taiwan, which was also the time when Beijing changed its attitude towards Taishangs due to changing cross-Strait relations. The three cities in China were chosen as the sites for the case studies because of sustained Taiwanese investments in these areas. Further interviews with Taishangs were conducted in Beijing, Shanghai and Kunshan between 2014 and 2016, in order to understand more recent changes in the phenomenon and to evaluate whether there had been any changes in Beijing's actions towards Taishangs in view of the change in from the DPP to the Nationalist One (KMT) as the ruling government in Taiwan since 2008 .

The data on mainland spouses were based on ethnographic work carried out through various long-term visits to Taiwan (between May 2008 and December 2015) and to China (in September 2011 and between January and August 2016). Data collection relied on about 150 in-depth interviews with marriage migrants, government officials, civil society practitioners as well as 
participant observation in various civil society organizations advocating for and providing support to marriage migrants in Taiwan. Although most of the fieldwork in Taiwan was carried out in the main cities of Taipei and Kaohsiung, the same sites where most mainland spouses resided, a number of interviews were also undertaken in other cities such as Taichung, Hualien and surrounding rural areas. Research in China was carried out mainly in the provinces of Fujian and Guangdong. Interviews with marriage migrants were conducted, depending on informants' availability, in their homes, in public spaces such as cafes and parks, and in the offices of civil society organizations.

An important feature of the research is our long-term exchanges with the two migrant groups, offering a longitudinal perspective of their experiences over time. In addition to the interviewees' narratives, this research is also informed by observations in the field, informal conversations with migrants and data collected from newspapers and periodicals throughout more than ten years of engagement with these two migrant groups.

\section{Transnational mobilities across the Strait}

The presence of Lupeis in Taiwan and Taishangs in China is well documented. At the end of August 2017, there were a total of 336,319 citizens of mainland Chinese origin married to a Taiwanese citizen (Ministry of Interior, 2017). Unlike Lupeis, it is difficult to calculate the number of Taishangs in China because they were not required to register apart from their commercial licenses. According to Chen (2014), there were about 230,000-250,000 Taishangs in China in 2014. If we consider the number of the Taiwanese hired by Chinese firms based in China and their families, their number could reach 1,000,000 (Ibid).

Due to the different nature of these two migrant communities - the movement of marriage migrants is related to the reproductive sphere while that of businessmen to the productive sphere — and their different trajectories - marriage migrants from a developing to a developed nation while businessmen move from a rich to an emerging nation - the two phenomena have been 
addressed by separate scholarship traditions. Mainland spouses have been considered in migration, family and gender studies (Cheng and Fell, 2014; Friedman, 2010; Lu, 2008; Momesso, 2015a, 2016; Yang and Lee, 2009) while Taiwanese businessmen have hardly been addressed as migrants. To date, most studies on Taiwanese businessmen pertain to their political implications on the evolution of cross-Strait relations (Keng and Schubert, 2010; Mengin, 2002; Schubert 2010). Yet, in the real world there are not such clear boundaries: marriage migrants may turn into productive actors by engaging in formal or informal occupations, while Taiwanese investors may make decisions related to the reproductive sphere when they marry local women and form families with them. Thus, the lives of these individuals could be characterized by shifting and overlapping identities, not only as productive and reproductive subjects, but also as emigrants, immigrants, returnees, or new residents.

In this research, we treat both Lupeis and Taishangs as transnational migrants or "transmigrants" (Glick Schiller et al., 1995) for two main reasons. Firstly, their lives share some of the fundamental features of transnational migrants. According to the literature, transnational lives are characterized by multiple and constant interconnections across borders and their public identities are configured in relationship to more than one nation-state (Basch et al., 1994; Glick Schiller et al., 1992). If the Taiwan Strait were not regarded as an international border or that Taiwan is not a sovereign state, the experiences of cross-Strait migrants present a rather different picture, similar to the cross of international borders. In China, the movements of mainland citizens to special zones, such as Taiwan, Hong Kong and Macao, have been strictly regulated and included in a special category, chujing ( $\square љ$ ), designating those who leave the country to go to Taiwan, Hong Kong and Macao (Zhu et al., 2008: 421). In Taiwan, in a context in which nationhood is not formally recognized, there is an autonomous state officially elected by its citizens and executing all the functions a state should implement, and a whole bureaucratic apparatus, under the National Immigration Agency, for managing migration was created, which mimics internationally recognized sovereign practices but at the same time, it does not openly challenge China's stance that Taiwan is not an independent nation-state (Friedman, 2015). Thus, Lupeis and Taishangs move across a border that function as an international border and develop multiple identities in relation to their belonging to two nation-states. When crossing borders and 
entering these two societies, these migrants encounter similar challenges as any other transnational migrants.

Secondly, both migrations are a manifestation of more recent neoliberal trends occurring globally and regionally which facilitate transnational mobilities. As Glick Schiller and colleagues (1995) suggest, transmigrants respond to these changes by searching for new opportunities across borders and establishing connections, building institutions, conducting transactions and influencing local and national events in the societies they belong to. Mainland spouses and Taiwanese investors are also part of broader flows of migration occurring on a global level. The peculiarity of cross-Strait relations makes these two cases different from other movements for marriage and investment.

\section{Transnational migrations and strong states}

Prioritizing the perspective of migrant actors, their flexible movements and hybrid identities, the transnational migration paradigm aims to offer a more suitable angle for looking at contemporary migrations in light of people's responses to recent economic, social and technological changes (Glick Schiller et al., 1992, 1995; Grillo et al., 2000; Guarnizo and Smith, 2008; Portes et al., 1999; Vertovec, 2009). Owing to the availability of new technologies, reduction of transportation costs, quicker travel times and the introduction of new, cheaper opportunities for networking across borders, migrants and other relevant social actors are now better connected than in the past. According to Smith (1994: 16), these have wrought significant changes: 'the spatial extension of once nationally contained households, social networks, and ethnic communities across national borders is producing new patterns of cultural appropriation and resistance by peoples whose current circumstances render them "borderless," and in that sense, at least, "unbound." Against this background, the state and its authority over border control, immigration legislation, polity, the ruling class and administrative apparatus seem to have weakened.

More recently, a critique within transnational migration theory countered that state authority could still be an important feature in migrants' lives. Indirectly, a country's position in the global order, as a developing or developed nation, has implications on the opportunities and constraints their citizens face when they move (Landolt et al., 1999; Robinson, 1998). Thus, although the 
option to migrate is available to an increasing number of people, citizens from developing nations face more constraints when moving across borders, whereas citizens from developed nations seem to be better positioned to enjoy the options offered by globalization. Directly, receiving states still have extensive power to decide over migrants' lives through regulations and policies that limit or facilitate the movements of certain categories of people, and the decision whom to include in and exclude from their polity through their citizenship laws and policies (Lister, 1997).

In some cases, sending states may decide to develop policies or establish institutions to allow greater representation of their emigrants in domestic politics - they could allow emigrants to participate in domestic elections or they could establish special economic programs aimed at facilitating remittances and investments (Kearney, 1995: 548). These initiatives are meant to recognize the existence of national communities beyond the territorial boundaries of the state and to extend the reach of the origin state over its emigrant population. In Varadarajan's (2014: 367) words, the new policies are aimed at integrating emigrants as part of a "larger "global" nation that is connected to, and has claims on, the institutional structures of the home state.'

In this way, a state may attempt to strengthen its authority over and connection with its emigrants. Yet, this would hardly turn into political claims over the territory where migrants reside. The cross-Strait context, though, is dominated by different logics. Like other states, the governments of China and Taiwan exercise their authority on migration matters through the regulation of cross-border movements, in the inclusion or exclusion of immigrant communities from their polities, in conferring or curtailing rights and privileges, or in recognizing the existence of their migrant populations on the other side of the Strait. Yet, as we will show throughout our analysis, in the cross-Strait context, the liberalization of the border between China and Taiwan and the consequent growth of cross-Strait economic and social exchanges implied for Beijing new opportunities to reinforce its nationalistic ideal of "one China."

To prove our point, it is crucial to look at migrant-state interactions by focusing on the perspective of state actors. Thus, it may be significant to refer to a political science model, which sheds light on states' actions vis-a-vis social groups. Stephen Krasner (1984) asserts that the state should be viewed as a main actor rather than a reflection of societal characteristics or an arena 8 
for social groups to compete. Krasner (1984) argues that there are three different types of states in terms of interacting with social groups within their polity: the weakest kind of state is one that is completely influenced by pressure from social interest groups; the intermediate type of state is one which may have some power to resist the pressure of social interest groups but is unable to impose any structural change on them; and the strongest kind of state is one which has the power to change and even create the structure of social interest groups. We argue that the Chinese government's interaction with Taishangs and Lupeis falls in the third type of state identified by Krasner. Yet, in a context in which the interests of these two social groups could match those of the Chinese government, rather than recurring to measures of control and coercion, Beijing offered benefits and privileges in exchange of support for its nationalistic goals.

This did not occur simultaneously for Taishangs and Lupeis though. If analyzed singularly, the two cases may offer a different picture of when and how Beijing relied on migrant communities to strengthen its nationalistic goals. Yet, by applying a longitudinal and comparative analysis, we may discover that, despite difference in terms of target groups, there may be continuity in terms of state's agenda. Krasner (1978) suggests that a state may be strong in some areas and weak in others, as policy decisions are often made in arenas that respond to narrow social interest groups, for instance agriculture and domestic economic policies. On the contrary, through our case studies, we will show that Beijing did not shape its policies according to existing social groups, it rather maintained the same objectives and made use of different migrant communities to achieve its aims. Against this picture, in this paper we maintain that migrant communities may also have a degree of power to negotiate with state's policies.

In the next sections, we provide an overview of the evolution of Beijing's interaction with Lupeis and Taishangs since the ban on cross-Strait social and economic exchanges was lifted in 1987.

\section{Taishangs: Of interest to the central and local governments}

\section{Initial phase}


When economic and social exchanges across the Taiwan Strait resumed in 1987, China and Taiwan were located at the two extremes of the global hierarchy of powers: at the top was Taiwan, one of the Asian tigers, at the bottom was China, a country which was still struggling with poverty and underdevelopment. Therefore, the opening of the frontier meant that China could enjoy the benefits of products and investments brought by Taiwanese to the mainland (Cheung, 2009; Wu 1994: 166); similarly, Taiwan could exploit the cheaper human resources of its neighbor to increase its competitiveness and to solve the demographic challenges of declining fertility rate and shortage of marriage partners (Wu 1994: 175). Thus, in the early years, crossStrait exchanges were regarded as part of global trends of migrations for marriage and business which also affected China and Taiwan. On the one hand, the exchanges can be interpreted as a reflection of economic inequality between the two countries; on the other hand, they can also be explained in terms of migrants' increased control over their lives vis-à-vis state authority.

In the early years, Beijing's initiatives toward cross-Strait migrant communities were motivated by economic interests. In the beginning, the incentives offered to Taiwanese investors (Economic Daily, 1990; United Daily, 1992), were mainly focused on attracting Taiwanese capital rather than using Taiwanese investors toward accomplishing the political goal of reunification. Due to the small number of Taiwanese investors, Beijing insisted on negotiating with Taipei at a governmental level rather through other channels. Furthermore, Beijing was cautious of foreign investors' influence on the political domain. In other words, Taiwanese businesses' economic significance had not yet spilled over into the political sphere. Thus, in the early years, the political connotations were rather neglected and economic interests instead were prioritized. Taiwanese investors, coming from an economically more developed country, were seen as sources of foreign investment and were welcomed by China like other foreign investors.

In the evolution of cross-Strait relations, since Beijing was not in a condition to directly reach social actors in Taiwanese territory, from the first half of the 1990s, Taishangs had started to become more important in the eyes of the Chinese government on account of their connections in Taiwan. Hence, if in the early years they enjoyed 'special status,' which included tax holidays and other incentives offered by the local governments, by the end of 1993, the strategic value of Taiwanese businesses is reflected in more meetings and discussions toward establishing more 
institutional channels. The realization by both central and local governments in China of the strategic value of Taiwanese businesses opened more space for Taiwanese investors to influence local governments. For local governments, Taiwanese investment not only brought prosperity to their locality but also more recognition from the central government, which enabled local governments to access more national resources, and often helped local officials to secure promotion. For the central government, more Taiwanese investments in China resulted in increasing leverage in negotiating the cross-Strait relationship. Thus, Beijing instructed local governments to keep favoring Taiwanese investors, which meant offering Taiwanese investors support 'case by case.' The central government encouraged local governments to forge special flexibility arrangements toward Taiwanese investors implicitly (Economic Daily, 1994). ${ }^{1}$ The Chinese government treated Taishangs slightly differently from investors from Hong Kong and Macao. In 1997, Hong Kong was returned to China and Macao, in 1999. Taiwan is China's last target for political reunification, therefore Taishangs continue to be more strategic and valuable to the Chinese government when compared to Hong Kong and Macao investors.

\section{Normalization phase}

Cross-Strait relations became more critical toward the end of the 1990s. Despite increased social and economic exchanges, diplomatic exchanges were interrupted: the Strait Exchange Foundation and the Association for Relations Across the Taiwan Strait ceased negotiations in 1999, and the exchanges between Beijing and Taipei struggled to continue. Furthermore, in these years, Taiwanese nationalism grew stronger.

Beijing responded to the changed conditions by reinforcing its connections with cross-Strait migrant communities. Taishangs had the greatest advantages in this phase as they acquired a new important function in the eyes not only of Beijing but also of Taipei, as both governments placed more value on the informal but still-existing channel: the regular meetings between both governments and Taiwanese business people. In 1998, the central government in China discussed in depth the creation of a favorable environment for enhancing the quality of cross-Strait

1

From interviews with Taishangs in China: T11 (14 November 2004, Tianjin); T12 (18 November 2004, Tianjin); K4 (30 November 2004, Kunshan); K12 (9 December 2004, Kunshan); D1 (20 December 2004, 11 Dongguan); D11 (23 December 2004, Dongguan). 
relations. Firstly, President Hu Jintao's wooing of Taiwanese people is actually a consistent principle of the central government (Keng and Schubert, 2010: 290-297). Local governments accordingly received an instruction to initiate as much interaction with Taiwanese people as possible. Secondly, through wider interaction, more and more Taiwanese politicians visited China. The Chinese government in fact welcomed more visiting Taiwanese politicians to China. It stated clearly that 'Beijing welcomes Taiwanese politicians who recognize the 1992 consensus on the "one China policy" to visit China for talks on improving cross-Strait relations' (Zheng and Lye, 2007: 68). Thirdly, the central and local governments allowed Taiwanese investors to attend the local People's Congress (PC) or People's Political Consultative Conference (PPCC) meetings; this decision also arose from rational calculation. Although these two institutions are consultative rather than policy-making bodies, Taiwanese investors still claimed that this gesture reassured them that the Chinese government would indeed endeavor to take account of Taiwanese investors' opinions.

In a phase in which Beijing could directly influence the people in Taiwan, Taishangs in the PRC gradually lost their significance in Beijing's priorities. Thus, for Taiwanese businesses, this was the worst period in terms of privileges. In 2008, the implementation of the new Labor Law meant that most Taiwanese small and medium-sized enterprises which were benefiting from cheap labor now faced a rather challenging situation. Before 2008, local officials made exceptions to facilitate Taiwanese investment in localities. From 2008 onwards, Taiwanese businesses have gradually come to receive 'equal treatment' with other investors, and the strategic value of Taiwanese businesses seems to have decreased. It is quite difficult to find direct evidence for this, though following a coincident development may illustrate the current strategic value of Taiwanese businesspeople in China.

Throughout the 1990s and the early 2000s, many Taiwanese businesses enjoyed initial benefits from local governments, for instance tax rebates and low-cost land rental. However, after fifteen years, most tax privileges have been suspended. The famous 'three waived; two halved' means that once an enterprise started to make profits, local government would waive the business tax for the first three years and charge half of normal business tax in the following two years. Therefore, from 2008 onwards, most Taiwanese businesses had already enjoyed this tax break. 
As for the land rental, at the beginning, in order to attract as much Taiwanese investment as possible, most local officials agreed to offer Taiwanese businesses unreasonably cheap rent. Nevertheless, these agreements were unreliable. Under the new circumstances, Taiwanese businesses therefore have to compete with not only other foreign investors but domestic investors equally. Most Taiwanese businesspeople remarked that in competition with other foreign investors, they might gain some trifling benefits because of their shared language and culture, but in competition with domestic enterprises, Taiwanese businesses did not have any advantages. After the Law of the People's Republic of China on employment contracts (also referred to as the new Labor Law) came into effect on 1 January 2008, many employers in China started to panic about their human resource expenditure because this new Labor Law provided detailed protection for labor (Baker and McKenzie, 2015). Interestingly, against fiercer competition, many Taishangs decided to move their family residence from Taiwan to China. With the PRC offering a more dynamic environment in terms of working and life opportunities, they strategically decided to raise their children in mainland China, despite its arguable political and educational environment, as this would facilitate their introduction in the job market once they grow up.

In terms of Taishangs' response to the Beijing government's warm welcome, most of them did not openly manifest their support to the Beijing government. The reason for Taishangs to migrate to China was economically driven, therefore they supported whichever party could protect their investment interests (Lee, 2014: 68-69). Yet, more recent developments showed some unprecedented cases. For instance, a Taishang named Want Want took the ownership of the Taiwanese media China Times and then openly supported the Beijing government through his media outlet (Lin and Lee, 2017). It has to be noted that Want Want is a valid but rare case, as most Taishangs, did not show their support of the Chinese government either in mainland China or in Taiwan, to the point that Schubert (2010) argues against any real political impact of this community in China and in Taiwan. Yet, since the second half of the 2000s, Beijing started to search for new potential allies on the other side of the Strait.

\section{Lupeis: From invisibility to recognition}

\section{Invisible and inconvenient}


While Taishangs are viewed as potential channels for achieving Beijing's nationalistic aims for which policies were developed to facilitate their businesses and movements in China, mainland spouses in Taiwan were outside of Beijing's sphere of influence for several years. As a matter of fact, cross-Strait marriage migration, throughout the 1990s, was still a relatively unimportant form of migration in the eyes of Beijing, and this could be attributed to several reasons. Firstly, in those years the main concern of Beijing was to promote economic development in the mainland (Wu, 1994: 166). As such, emigration flows for reproductive reasons beyond the territory may have seemed of little significance for its main agenda (Momesso, 2017: 911). Furthermore, cross-Strait marriage migration had not yet obtained statistical relevance throughout the 1990s as quotas imposed by Taiwanese authorities restricted the development of the phenomenon (Lu, 2008: 152; Tu and Li, 1999: 502). With increasing numbers by the end of the 1990s, cross-Strait marriage migration assumed more significance. Between 1998 and 2009, each year, more than 50 percent of all the marriages involving a non-Taiwanese citizen in Taiwan were with a spouse from the mainland (Ministry of Interior, 2010). Finally, earlier crossStrait marriages carried a negative label, as they often involved women from rural areas marrying older men from Taiwan for economic reasons. Thus, at the time, marriage migration to Taiwan was perceived as a shame of the nation, symbolizing poverty and underdevelopment. Under the circumstances, marriage migrants were not expected to make any contribution to serving Beijing's goals, when the state was struggling to establish a new image of a renewed and emerging China nationally and internationally (Wang, 2015: 20). For these reasons, marriage migrants may have remained invisible in the eyes of Beijing.

On the other hand, the increasing number of marriage migrants from China since the late 1990s were a matter of concern to Taipei. As a matter of fact, the potential negative impact of Lupeis on issues related to national security and sovereignty led to the Taiwanese government's tightening of restrictions on Lupeis' access to citizenship rights (Cheng and Fell, 2014; Friedman, 2010; Liao, 2008; Yang and Lee, 2009). The Lupeis posed a concern because of their potential to affect the future of Taiwan as a sovereign nation through their right to vote and to be elected. Thus, lengthening the process to become a naturalized Taiwan citizen was aimed at reducing their political impact, and this was enforced by limiting their right to hold public office, set up political parties or assume positions in intelligence units or certain national defense ranks, 14 
for at least ten years after the acquisition of Taiwanese citizenship. These restrictions were meant to reduce the possibility that they will interfere with the sensitive spheres of politics and national defense in Taiwan (Friedman, 2010: 80). The logic of national security was further emphasized by a differentiated citizenship system, which imposed a longer process to marriage migrants from the mainland (originally eight years, and since 2009 six years instead of the four-year process for international marriage migrants) to be fully integrated as nationals in Taiwan (Friedman, 2010, 2015; King, 2010; Liao, 2008; Yang and Lee, 2009). Throughout the 1990s and early 2000s, mainland spouses were a problem mainly for Taipei and not for Beijing.

\section{Praising Lupeis}

Interestingly, since the second half of the 2000 s, the political potential of mainland spouses started to attract the interest of Beijing. As Momesso (2017) argues, the Chinese government's first step to reach out to these migrants was showing interest in connecting with them and in understanding their condition and situation in Taiwan (pp. 911-913). Thus, as the representatives of two civil society organizations helping mainland spouses in Taiwan explained, Chinese local authorities contacted them in the second half of the 2000s. ${ }^{2}$ In the following years, delegations of mainland spouses were invited to visit various provinces in China. As Momesso (2017) also states, these meetings were followed by exchange visits of Chinese delegations in Taiwan ( $p$. 912). These earlier exchanges were kept at low profile and were often closed-door initiatives for a few selected invitees. Yet they marked the beginning of a new era with regard to the interactions between China and Lupeis in Taiwan.

Indeed, when the Kuomintang (KMT) won the national elections in Taiwan in 2008, these informal exchanges took new directions. As President Ma Ying-jeou pushed for a more accommodating approach with the People's Republic of China (PRC), describing Taiwan under the Greater China framework, rather than as an independent state, and referring to relations between China and Taiwan as 'special relations between region-to-region on equal footing' (Muyard, 2010: 6), he favored the position of the PRC with regard to cross-Strait relations. This

\footnotetext{
2

Interview with the ex-President of the Marriage Association of Two Sides of China (中華兩岸婚姻協會促進 會), 31 May 2011, Taipei; Interview with the President of the Chinese Association of Relief and Ensuing Service (中 華救助總會), 11 July 2011, Taipei. 15
} 
was accompanied by various adjustments implemented by the two governments throughout the years, which favored further integration between the two sides. First the 'three links,' officially established in 2008 after almost thirty years of negotiation led to the following: it legalized post, trade and travel between Taiwan and China; direct flights across the Strait, previously available only during the Chinese New Year and other festivities were established on a regular basis in 2009; the Economic Cooperation Framework Agreement (ECFA), a preferential trade agreement reducing tariffs and commercial barriers between the two sides, was signed in 2010; and group tourism from mainland China was opened in 2008 and, in 2011, it was opened to independent travelers (King, 2011: 190; Muyard, 2010: 6). The easing of restrictions on PRC citizens' movements to Taiwan, as well as the opening up of direct flights between the PRC and Taiwan, gradually became important assets in facilitating movement across the Strait for all people in general and for Lupeis in particular (Momesso, 2015a).

The new framework promoted by Ma Ying-jeou also offered new opportunities for Beijing to take actions in Taiwanese territory. The Chinese government was able to extend its influence in Taiwan and reach out to certain communities in Taiwan. Under the 'three middles and one youth' policy (- “ common people in central and southern Taiwan, and young people, China placed new emphasis on better understanding the thoughts and sentiments of the people in Taiwan (Romberg, 2014: 7). Under this policy, mainland spouses and their family members, particularly their children, became one of the targets of China in Taiwanese territory (Momesso 2017: 913).

Thus, since 2012, exchange activities between mainland spouses' civil society groups in Taiwan and Chinese authorities have multiplied. Besides the regular activities organized by local authorities, interactions with the central government were made official in 2012, when Beijing launched its first Cross-Strait Family Forum ( $\sim \square^{\frac{2}{l}} z \quad$ ) in Xiamen (Fujian province). At the end of the same year, nationwide bodies focused on cross-Strait families - the Cross-Strait

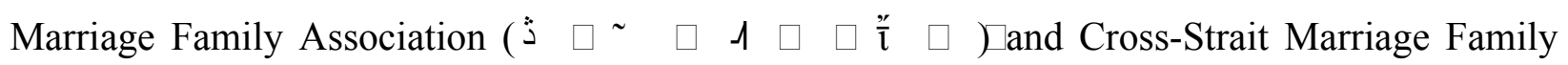

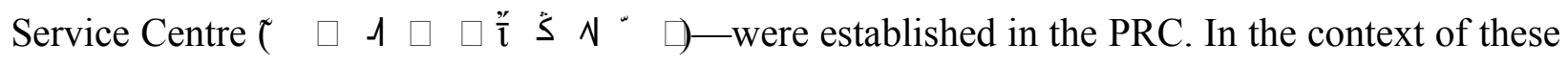
initiatives, mainland spouses and their families were praised as bridges across the two societies and as living examples of successful cross-Strait peaceful development and unification. For 
instance, in one of the reports describing the First Cross-Strait Family Forum and published by the periodical, Relations Across Taiwan Straits (2012), Dou Yupei, Deputy Minister of the Ministry of Civil Affairs and President of the Cross-Strait Marriage Family Association, was reported as stating that cross-Strait families may forge cross-Strait relations by 'promot[ing] human exchanges across the Strait,' 'strengthen[ing] the blood linkages between compatriots,' 'continu[ing] the common ancestral blood of the Chinese nation,' 'pass[ing] on to future generations the common mark of the Yellow emperor' (p. 41). A year later, Ye Kedong, Deputy Director of the Taiwan Affairs Office of the State Council, turned the message into a political slogan during the Second Cross-Strait Family Forum: 'cross-Strait peaceful development needs the support and effort of cross-Strait families, and the happiness of cross-Strait families cannot exist without peaceful unification across the Strait' (Relations Across Taiwan Straits, 2013: 54). Emphasizing their contribution to material as well as reproductive terms, cross-Strait marriage migrants were turned into symbols to legitimize cross-Strait unification.

This political message received different degrees of appeal among Lupeis' communities. A male spouse from Liaoning City, Dongbei Province, explained how the new interest showed by China toward Lupeis could result in advantages for the community of mainland spouses as well as for China:

So the mainland government shows increasing interest toward mainland spouses. To be a mainland spouse means a quite happy thing now. Actually, if you compare with other spouses' nationalities, the only group receiving support from their government are those from the mainland. [...] What does this represent? Two aspects, one is the fact that mainland economy has improved extensively. When a country's economy is good, it will invest more money on its citizens' welfare and care. So China, with a betterment of its economy, has started to think about its communities abroad. In this way, communities abroad can give even more help to their country. Although we are not regarded as a community abroad, however offering support to spouses married to Taiwanese is common thing. [...] I do not think that there are other reasons, it is mainly to favor a stable social integration of mainland spouses in Taiwan. To let us understand, we must blend into Taiwanese society. To prepare us to become Taiwanese citizens, and to have a 
more stable life here. So more care will also turn into a greater feeling for us. (Interview with male spouse, 22 December 2016, Kaohsiung, Taiwan)

China's new welcoming approach had a clear impact among mainland spouses' communities in Taiwan. When civil society organizations from China came to visit, marriage migrants often manifested their appreciation for the support and interest shown by Beijing. Several mainland spouses built on Beijing's narrative and positioned themselves as bridges across the Strait, able to help social and economic development on both sides thanks to their extensive knowledge of and networks on each side. ${ }^{3}$ If their main objective was to make money, for instance, by selling Taiwanese products in China through Internet websites or by working as agents for Chinese tourists and investors in Taiwan, they often promoted their actions as way to contribute to crossStrait economic development.

In contrast with the stance embraced by Taishangs, several mainland spouses went beyond economic and social operations and manifested their support for China in different ways. For instance, when Zhang Zhijun, Director of the Taiwan Affairs Office, was on a visit in Taiwan in June 2014, various groups of mainland spouses gathered to show their support for him in the midst of several anti-China demonstrations that arose on this occasion. Also, since 2010, a number of political parties, set up by mainland spouses and with various degrees of support for the ideal of cross-Strait unification, emerged in Taiwan: the China Production Party ( $\square \square$ 亿

), ${ }^{4}$ the Chinese New Resident Party ( $z^{*}{ }^{\prime} \jmath_{\text {z }} \quad$ ), ${ }^{5}$ and the New Resident Republican Party ( $\lrcorner z^{c} \square$ ). ${ }^{6}$ The emergence of these political parties is an important change for mainland spouses' public actions in Taiwan. Distancing from the strategies previously applied by civil society organizations which avoided any identification with political parties in Taiwan, either pro-independence or pro-unification (King, 2011), these parties represent not only marriage migrants' earlier experiments to bring the voice of new residents into Taiwan politics, but also

3

Interview with a mainland spouse member of the Taichung City Mainland Spouse Care Promotion Association (台中市陸配關懷促進會), 25 October 2015, Taichung.

5

6

18

Party website: https://web.archive.org/web/20141016171743/http://scd.com.tw/

Party website: http://cniparty.weebly.com

Party website: https://sites.google.com/site/herry1788/ 
the first attempts to promote the nationalistic goals of 'one China' in Taiwan. For the first time, mainland spouses explicitly took a stand in favor of the nationalistic dream promoted by Beijing. The political parties explicitly referred to the ideal of cross-Strait reunification. For instance, the booklet of the Chinese New Residents Party sets as one of its long-term aim that of reestablishing the "greatness of the Chinese Nation." Also, Lu Yuexiang, the chairwoman of the China Production Party, stated:

We acknowledge the 1992 consensus, we support cross-Strait unification. Cross-Strait peace is important, it allows us to move back and forth and make friends, but unification is the final aim, the final dream! Unification is one country, one China. It is not enough to have cross-Strait development, we need to reach cross-Strait unification. (Interview with Lu Yuexiang, 24 May 2016, Xiamen, Fujian Province)

It is hard to predict, at this experimental stage, the potential impacts of these actions. Initiated as a response to the interest shown by China toward this community, they should also be interpreted in light of other factors, including mainland spouses' legal discrimination and marginalization in Taiwan, a neglect of their interests and needs by the main parties, a politicization of their daily lives and intentions, and a process of gradual acquisition by marriage migrants of new means to change their lives (Momesso 2015b).

With very limited resources and honor and recognition, Beijing strategized this community of migrants to promote its message of a unified China under the Communist Party. It is hard to say, at this stage, whether this tactic will have any impact on cross-Strait policies and on the future of Taiwan. Yet, these examples clearly show that a state may take advantage of transnational mobility to strengthen its nationalistic goals.

\section{Concluding remarks}

In light of rising cross-border connections, mobility and exchanges, there is a view that states have lost their authority over their citizens, who now enjoy greater control and flexibility over their movements and their identities. Focusing on mainland marriage migrants in Taiwan and Taiwanese investors in China, this paper problematizes this view and offers a more nuanced 
picture of the negotiation between the state and migrants in the cross-Strait context which is marked by cross-border mobility on the one hand, and contested Taiwanese sovereignty, on the other hand. Although some aspects of cross-Strait migration flows exhibit challenges to the authority of the state, in other aspects, a reconfiguration, and even reconfirmation, of state power and influence are also apparent.

The cross-Strait case, thus, could be a significant example of understanding the relative power of the state in a context of intense cross-border mobility. The ongoing conflict between Beijing and Taipei over the Taiwan territories, add another layer of complexity in the negotiation between China and Taiwan on social and economic exchanges. Thus, in the eyes of Beijing, cross-Strait migrants are important political tools who could serve to reinforce and confirm the nationalistic ideal of one China under the Communist Party.

Employing a state-centered approach, and building on a comparative analysis of the interaction between Beijing and the Lupeis and Taishangs, this paper found that increased cross-border mobility does not necessarily erode the power of state actors over migrants and its territory and borders. Paradoxically, increased cross-border social, economic and cultural exchanges have contributed to reinforcing Beijing's nationalistic goals. Our comparative and longitudinal analysis shows that the Chinese state has been strategic in engaging migrant communities in order to serve its goals more efficiently. Thus, if from the perspective of a migrant community, the power of a state may be more or less compelling, from the perspective of the state, it exercises choice in managing migration in the cross-Strait corridor.

In the case of Taishangs, the study found that initially, the central and local Chinese governments did not plan to use Taiwanese investors for strategic purposes. Taiwanese investors became valuable under conditions of changing cross-Strait relations and the consolidation of democracy in Taiwan. On the other hand, the gendered migration flows of marriage migrants from China to Taiwan did not reach the attention of Beijing until its impact in Taiwanese territory became apparent and cross-Strait relations entered a more favorable phase. The change also offered increased latitude of influence and power to Beijing in Taiwanese territory. Thus, mainland spouses became a positive asset for Beijing particularly after 2008 when the KMT came back into power in Taiwan.

20 
The state-centered approach taken by the study helped to show how state actors may reinforce their authority in a context of increased cross-border exchanges and in adjusting to the changed environment, offering privileges and honors to migrants in order to establish alliances and gain their support.

In the context of increasing transnational migration flows, one strand in the literature sees the state as losing power and authority; another strand suggests that states have adjusted their actions to the changed environment by turning into transnational actors or by further reinforcing their control within their borders. The case of cross-Strait migrations shows a rather different picture. In the increasing population exchanges for marriage and investments across the Taiwan Strait, Beijing did not lose authority but instead had new opportunities to reconfirm its nationalistic ideal of a unified China. This paper also highlighted that state influence is not only to be identified in the power of controlling and restricting migrants' freedom to move, but also in according privileges and honors to migrants in support of achieving the main goals of the state. 


\section{References}

Baker and McKenzie (2015) Law of the People's Republic of China on employment contract. Available at: www.bakermckenzie.com/-/media/files/insight/publications/2015/06/chinaemployment-law-update-june-2015/al_china_employmentupdate_jun15.pdf?la=en

Basch L, Glick Schiller N and Szanton-Blanc C (1994) Nations Unbound: Transnational Projects and the Deterritorialized Nation-state. New York: Gordon and Breach.

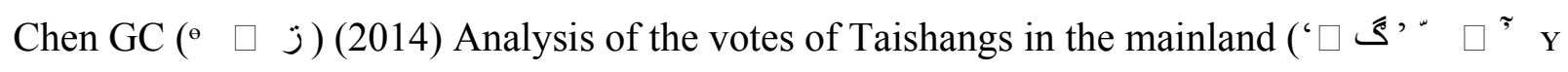
$\Lambda$ z $\square$ ). Chinese Academy of Social Sciences Taiwan Institute/Expert Forum (“ $\square \mathrm{W}$

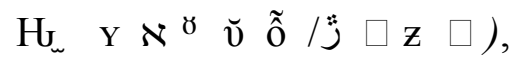

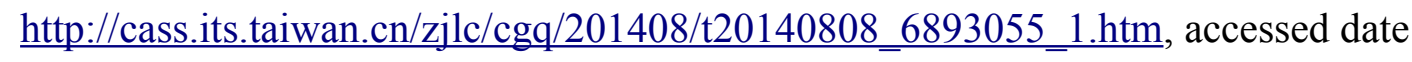
September $10^{\text {th }} 2017$.

Cheng I and Fell D (2014) The change of ruling parties and Taiwan's claim to multiculturalism before and after 2008. Journal of Current Chinese Affairs 43(3): 71-103.

Cheung GCK (2009) Governing Greater China: Dynamic perspectives and transforming interactions. Journal of Contemporary China 18(58): 93-111.

Economic Daily (1990) In order to attract Taiwanese investment, the CCP decided to offer Taiwanese businessmen special benefits. 16 August, p.3.

Economic Daily (1994) The CCP approved Taiwanese investment by case: the uncertainty of Taiwanese investment in China increased. 13 June, p.3.

Friedman S (2010) Marital immigration and graduated citizenship: Post-naturalization restrictions on Mainland Chinese spouses in Taiwan. Pacific Affairs 83(1): 73-93. 
Friedman S (2015) Exceptional States. Chinese Immigrants and Taiwan Sovereignty. Oakland: University of California Press.

Glick Schiller N, Basch N and Blanc-Szanton C (1992) Transnationalism: A new analytic framework for understanding migration. In: Glick Schiller N, Basch N and Blanc-Szanton C (eds) Towards a Transnational Perspective on Migration: Race, Class, Ethnicity, and Nationalism Reconsidered. New York: The New York Academy of Science, pp. 1-24.

Glick Schiller N, Basch L and Blanc-Szanton C (1995) From immigrant to transmigrant: Theorizing transnational migration. Anthropological Quarterly 68(1): 48-63.

Grillo R, Riccio B and Salih R (2000) Here or There? Contrasting Experiences of Transnationalism: Moroccans and Senegalese in Italy. Brighton: University of Sussex.

Guarnizo LE and Smith MP (2008) The location of transnationalism. In: Smith MP and Guarnizo LE (eds) Transnationalism from Below: Comparative Urban and Community Research. London: Transaction Publishers, pp. 3-34.

Harding H (1993) The concept of "Greater China": Themes, variations and reservations. The China Quarterly 136(December): 660-686.

Kearney M (1995) The local and the global: The anthropology of globalization and transnationalism. Annual Review of Anthropology 24: 547-565.

Keng S and Schubert G (2010) Agents of Taiwan-China unification? The political roles of Taiwanese business people in the process of cross-Strait integration. Asia Survey 50(2): 287-310.

King W (2011) Taiwanese nationalism and cross-Strait marriage. Governing and incorporating mainland spouses. In: Guenter S and Damm J (eds) Taiwanese Identity in the 21st Century: Domestic, Regional and Global Perspectives. Abingdon: Routledge, pp. 176-193. 
Krasner SD (1978) Defending the National Interest: Raw Materials Investment and U.S. Foreign Policy. Princeton, NJ: Princeton University Press.

Krasner SD (1984) Approaches to the state: Alternative conceptions and historical dynamics. Comparative Politics 16(2): 223-246.

Landolt P, Autler L and Baires S (1999) From hermano lejano to hermano mayor: The dialectics of Salvadoran transnationalism. Ethnic and Racial Studies 22(2): 290-315.

Lee CY (2014) From being privileged to being localized? Taiwanese businessmen in China. In: Chiu K-F, Fell D and Lin P \(eds) Migration to and from Taiwan Strait. London: Routledge, pp. 57-72.

Liao YH (2008) The exclusionary Taiwan immigration laws. Migrant Monitor 2008: 39-46 Available at: www.apmigrants.org/articles/publications/Migrant\%20Monitor/Migrant $\% 20$ Monitor\%202008.pdf

Lin, LY and Lee CY (2017) When business met politics. China Perspective 2017(2): 37-47.

Lister R (1997) Citizenship: Towards a feminist synthesis. Feminist Review 57(1): 28-48.

Lu M (2008) Gender, marriage and migration: Contemporary marriages between mainland China and Taiwan. Unpublished PhD Thesis, Leiden University, Netherlands.

Mainland Affairs Council (2015) Table 10. Taiwan Approved Outward Investment by Country (Area). Available at: www.mac.gov.tw/public/MMO/MAC/269_10.pdf

Mainland Affairs Council (2016) Preliminary statistics of cross-Strait economic relations. Available at: www.mac.gov.tw/public/Data/6216141702.pdf

Mengin F (2002) Taiwanese politics and the Chinese market: Business's part in the formation of a state, or the border as a stake of negotiations. In: Mengin F and Rocca J-L (eds) Politics in China: Moving Frontiers. New York: Palgrave Macmillan, pp. 232-257. 
Ministry of Interior (2010) Statistical data of marriages with a foreign, mainlander and Hong

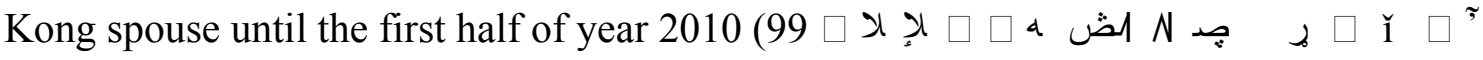

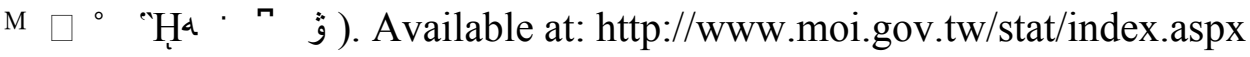

Ministry of Interior (2017) Statistical data of foreign spouses and mainland (Hong Kong and Macao included) spouses in each county and city according to the status ( $(\check{\lambda}$ ¿

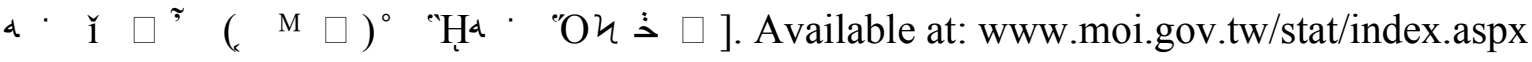

Momesso L (2015a) Change and permanence in contemporary Chinese families: A case study of marriage across the Taiwan strait. In: Ehlers H, Kalisch C, Linke G, et al. (eds) Migration - Geschlecht - Lebenswege. Münster: LIT Verlag, pp. 51-76.

Momesso L (2015b) The politics of Chinese spouses in Taiwan. China Policy Institute: Analysis (Online journal of The China Policy Institute, University of Nottingham). Available at: http://blogs.nottingham.ac.uk/chinapolicyinstitute/2015/12/24/the-politics-of-chinesespouses-in-taiwan/

Momesso L (2016) From someone, to no-one, to a new- one: A subjective view of Taiwan's immigration policies in the context of multiculturalism. Berliner China-Hefte 47: 24-36.

Momesso L (2017) Marriage migration and state interests: Reflections from the experiences of marriage migrants from the People's Republic of China in Taiwan. Asiatische Studien 70(3): 903-920.

Muyard F (2010) Mid-term analysis of the Ma-Ying-jeou administration. The difficulty of delivering the (right) goods. China Perspectives 83(3): 5-21.

Portes A, Guarnizo LE and Landolt P (1999) The study of transnationalism: Pitfalls and promise of an emergent research field. Ethnic and Racial Studies 22(2): 218-237.

Relations Across Taiwan Straits (2012) Serving cross-Strait sweet cause and common effort. Interview with Dou Yupei, Deputy Minister for Civil Affairs and President of the Cross- 


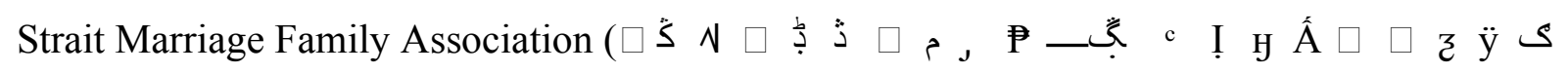

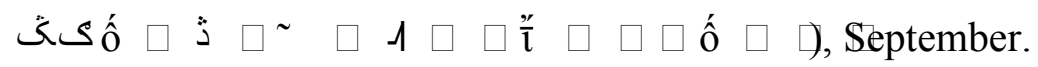

Relations Across Taiwan Straits (2013) Sharing happiness, cheering up for love. Report of the


مبJuly, pp. 53-56.

Robinson WI (1998) Beyond nation-state paradigms: Globalization, sociology, and the challenge of transnational studies. Sociological Forum 13(4): 561-594.

Romberg AD (2014) Cross-Strait relations: Portrayals of consistency calm on the surface, paddling like hell underneath. China Leadership Monitor 45 (Fall): 1-26.

Schubert G (2010) The political thinking of the mainland Taishang: Some preliminary observations from the field. Journal of Contemporary Chinese Affairs 39(1): 73-110.

Smith MP (1994) Can you imagine? Transnational migration and the globalization of grassroots politics. Social Texts 39: 15-33.

Tu EJC and Li SM (1999) Inter-regime marriage and mobility: The case of Mainland China and Taiwan. Journal of Contemporary China 8(22): 499-516.

United Daily (1992) The CCP will increase the investment benefits to Taiwanese Investors. 22 October, p.4.

Varadarajan L (2014) The transnationalism of the embattled state. New Political Science 36(3): 366-386.

Vertovec S (2009) Transnationalism. London: Routledge.

Wang P (2015) Media presentations of cross-Strait marriage in contemporary China. China Media Research 11(2): 17-28.

Wu HH (1994) Bridging the Strait. Taiwan, China, and the Prospects for Reunification. Hong 26 
Kong: Oxford University Press.

Yang WY and Lee PL (2009) The citizenship dilemma of mainlander spouses in Taiwan: The

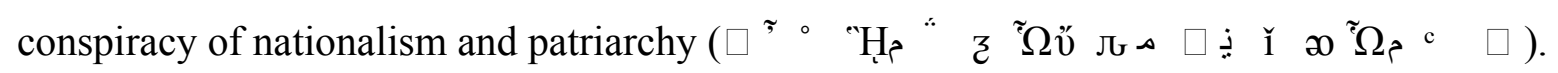
Taiwan Democracy Quarterly ( e " g ) 6(3): 47-86.

Zheng YN and Lye LF (2007) China's new nationalism and cross-Strait relations. International Relations of the Asia-Pacific 7: 47-72.

Zhu Y, Lin L-Y, Qi X-H and Xia J-L (2008) China. Asian and Pacific Migration Journal 17(34): 419-428. 